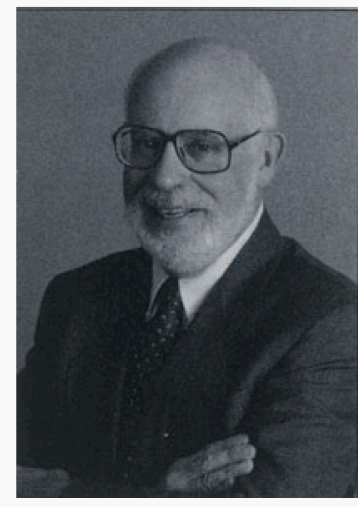

\title{
Steering a course to farmland protection
}

\section{Alvin Sokolow \\ Public Policy Specialist UC Davis}

$T_{\text {larisen }}^{\text {he }}$ his issue of California Agriculture offers a small glimpse of a large problem - the urbanization of California farmland, a process which contributed to the $23 \%$ loss of this resource between 1950 and 1993.

The topic of farmland conversion often evokes emotion, speculation, and hand-wringing. Farmland suggests different images to different Californians. It can be any or all of these things:

- an irreplaceable natural resource,

- a type of industrial use,

- a generator of income and prosperity,

- a landscape amenity and antidote to urban congestion,

- an inefficient consumer of precious water, or

- a source of odor, noise and chemical danger.

If you are a farmland owner approaching retirement with a small income but a big property asset, your view of the resource quite naturally is different than if you are a suburban homeowner who likes the nearby farmland because it is pretty and adds to the rural ambience.

To the extent that the Division of Agriculture and Natural Resources (DANR) focuses on farmland-urbanization as a subject for research and education, we must steer an independent course through the thicket of conflicting views, values and personal preferences. We appreciate the critical contribution of good land to the viability of California agriculture, and we recognize the necessity of preserving for future generations the farmland base in this rapidly urbanizing state. But, if our objective is to inform policymakers and the public in a meaningful and credible fashion, we must go beyond the images and add to the factual understanding of the farmland conversion problem. This means examining the origins and dimensions of the problem, understanding its relationship to other resource and economic issues, and evaluating the feasibility of alternative solutions.

In at least three areas, DANR researchers and educators are making important contributions to resolving farmland-urbanization problems. One area is production agriculture research, carried out in laboratories and fields, which helps reduce the incompatibilities between agriculture and urban neighbors. This work includes myriad advances in integrated pest management, plant breeding and genetic engineering (leading, for instance, to disease-resistant varieties requiring fewer pesticides) and agricultural engineering to improve field spray technology, agricultural waste disposal and irrigation efficiency.

A second area is public policy research and education advanced by DANR social scientists. This includes the workshops and publications produced in the past decade by the Agricultural Issues Center on land use and urban growth issues. Among them are studies of the Williamson Act, Central
Valley urbanization, and conflicts at the agriculture-urban edge.

Third is the educational work of Cooperative Extension advisors and county directors at the local level where land use decisions concerning farmland are made. Their expertise is sought on the agricultural consequences of urban development - as members of technical advisory committees that review policies and development proposals, as individual advisors to boards of supervisors and other county agencies, as cooperators on land resource issues with resource conservation districts, and as participants in public education projects.

The five articles and two sidebars in the special section address two separate but related public policy questions: (1) How do we minimize the conversion of productive farmland, while still accommodating the housing, economic and environmental needs of an urbanizing state? and (2) How do we reduce the conflicts and negative impacts at the farm-urban edge, making it possible for commercial agricultural and nonfarm residents to coexist peacefully in close proximity to each other?

The articles - condensed from chapters of an upcoming Agricultural Issues Center publication - deal with practical aspects of public policy: the effectiveness of state farmland protection, local government approaches to the same, the sources of edge conflicts, land speculation in agricultural areas in the path of urbanization, and the use of conservation easements by land trusts to protect farmland. Four of the five authors included in this section are not directly associated with $\mathrm{UC}$, a reflection of the expert involvement in these areas by many other statewide and local organizations.

These papers barely scratch the surface of understanding the farmland-urbanization problem. The conversion and edge issues have multiple dimensions, some of which include water-land use relationships, the effects of farm family succession, and the validity of projections of farmland loss. We should also look into the effectiveness of different policies and techniques for minimizing the problem, such as higher development densities, better urban design at edges, conservation easements and urban limit lines.

All of this suggests an ambitious research and educational agenda that will carry us into the 21st Century. It is an agenda that cannot possibly be carried out by Division personnel acting on their own. It requires collaboration with other California institutions, including state and local governments, nonprofit organizations, industry groups, other universities, and other parts of UC. Farmland-urbanization issues are long-term concerns, important to California's future. In cooperation with others, the Division will continue to apply the fruits of new knowledge to these issues.

Special thanks to Al Sokolow, guest editor for the special section. 